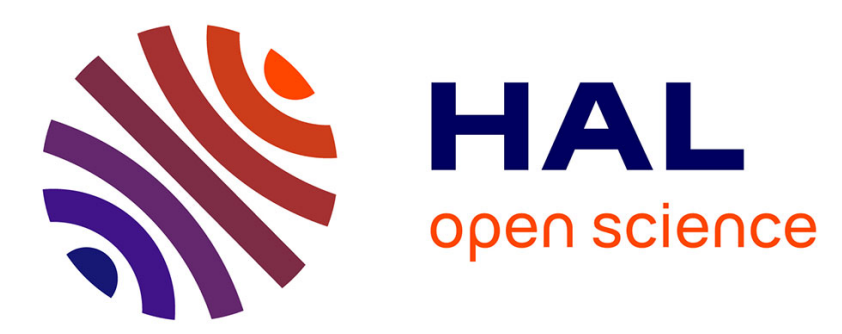

\title{
Correlation Between the Reactivity Towards Oxygen and the Coercitivity in Submicron Vanadium Ferrite Spinels
}

\author{
V. Nivoix, B. Gillot, D. Aymes, P. Perriat, N. Millot, S. Rousseau, M. Guyot
}

\section{To cite this version:}

V. Nivoix, B. Gillot, D. Aymes, P. Perriat, N. Millot, et al.. Correlation Between the Reactivity Towards Oxygen and the Coercitivity in Submicron Vanadium Ferrite Spinels. Journal de Physique IV Proceedings, 1997, 07 (C1), pp.C1-237-C1-238. 10.1051/jp4:1997190 · jpa-00255137

\section{HAL Id: jpa-00255137 https://hal.science/jpa-00255137}

Submitted on 1 Jan 1997

HAL is a multi-disciplinary open access archive for the deposit and dissemination of scientific research documents, whether they are published or not. The documents may come from teaching and research institutions in France or abroad, or from public or private research centers.
L'archive ouverte pluridisciplinaire HAL, est destinée au dépôt et à la diffusion de documents scientifiques de niveau recherche, publiés ou non, émanant des établissements d'enseignement et de recherche français ou étrangers, des laboratoires publics ou privés. 


\title{
Correlation Between the Reactivity Towards Oxygen and the Coercitivity in Submicron Vanadium Ferrite Spinels
}

\author{
V. Nivoix, B. Gillot, D. Aymes, P. Perriat, N. Millot, S. Rousseau and M. Guyot* \\ Laboratoire de Recherche sur la Réactivité des Solides, UMR 5613, BP. 138, 21004 Dijon cedex, France \\ * Laboratoire de Magnétisme et d'Optique de Versailles, 78035 Versailles, France
}

\begin{abstract}
Nanometric powders of $\mathrm{Fe}_{2} \mathrm{VO}_{4}$ and $\mathrm{Fe}_{1.84} \mathrm{~V}_{0.92} \mathrm{Co}_{0.23} \mathrm{O}_{4}$ have been synthetised by "chimie douce" process. The cations in the spinel structure can oxidize at low temperatures without any phase transformation leading to cationdeficient spinel with formula $\mathrm{Fe}_{2} \mathrm{VO}_{4} \delta$ and $\mathrm{Fe}_{1} .84 \mathrm{~V}_{0.92} \mathrm{Co}_{0.23} \mathrm{O}_{4+\delta}$, where $\delta$ is the deviation from stoichiometry, due to a change of the anion-cation ratio, consecutive to formation of vacancies. The oxidation, investigated by thermogravimetry, involves several stages, each stage corresponding to the oxidation of one oxidizable cation, $\mathrm{Fe}^{2+}$, $\mathrm{V}^{2+}, \mathrm{V}^{3+}$ on $\mathrm{B}$ (octahedral) or A (tetrahedral) sites. Coercivily has also been studied, revealing that the coercive field increases with the rate of oxidation.
\end{abstract}

\section{ELABORATION OF VANADIUM FERRITES}

The nanocrystalline particles were prepared by coprecipitation by adding an aqueous solution containing suitable amounts of $\mathrm{Co}^{2+}, \mathrm{Fe}^{2+}, \mathrm{Fe}^{3+}, \mathrm{V}^{3+}$ to tricthylamine. It is followed by a heat treatment which includes calcination at $500^{\circ} \mathrm{C}$ for $10 \mathrm{hours}$ under $\mathrm{O}_{2}$, and reduction at $500^{\circ} \mathrm{C}$ for 5 hours under $\mathrm{H}_{2} / \mathrm{N}_{2} / \mathrm{H}_{2} \mathrm{O}$ mixtures. The relative contents of the different gases 10 obtain stoichiometry were obtained by studying the deviation from stoichiometry, $\delta$, as a function of the oxygen partial pressure, $\mathrm{pO}_{2}$, given by the gas mixture and measured by an EMF cell : the stoichiometry $(\delta=0)$ is obtained, at a given temperature, in the range of oxygen partial pressure where $\delta$ does not vary with $\mathrm{pO}_{2}$ [1]. For the two investigated ferrites, the atmospheric conditions for obtaining the stoichiometry depends on the composition of the spinel: $\mathrm{pO}_{2}=10^{-28} \mathrm{~atm}$ at $500^{\circ} \mathrm{C}(\mathrm{N2}=98.4 \%$, $\left.\mathrm{H}_{2}=1.6 \%\right)$ for $\mathrm{Fe}_{1.84} \mathrm{~V}_{0.92} \mathrm{C}_{0.23} \mathrm{O}_{4}, \mathrm{pO}_{2}=10^{-29}$ atm at $500^{\circ} \mathrm{C}\left(\mathrm{N}_{2}=87.5 \%, \mathrm{H}_{2}=12.5 \%\right)$ for $\mathrm{Fe}_{2} \mathrm{VO}_{4}$. The particles have a size of $40 \mathrm{~nm}$, and are identified to be a pure spinel structure. The lattice constant is equal to $8.382 \AA$ for

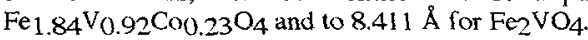

\section{REACTIVITY TOWARDS OXYGEN: COMPARISON BETWEEN NANOMETRIC AND COARSE GRAINS}

The oxidation of $\mathrm{Fe}_{2} \mathrm{VO}_{4}$ is followed by thermogravimetry for linear heating rate experiments. Figure 1 compares the rate of oxidation in $\mathrm{Fe}_{2} \mathrm{VO}_{4}$ for coarse $(300 \mathrm{~nm})$ and nanometric powders $(40 \mathrm{~nm})$ and the rate of oxidation in nanometric vanadium ferrites containing or not Co cations. For coarse grains, the DTG curve has been carefully studied by additional experiments : X-ray diffraction, XPS and FT-IR spectroscopy. Three peaks (Figure la) have been evidenced, corresponding successively to the oxidation of the $\mathrm{Fe}^{2+}$ cations on $\mathrm{B}$ sites, the $\mathrm{V}^{2+}$ cations on $\mathrm{B}$ sites and finally the $\mathrm{V}^{3+}$ cations on $\mathrm{B}$ sites [2]. The oxidation temperature of a cation is strongly correlated to the cation-oxygen distance, which depends both on the valence state and the location on A or B sites [3]. Compared with coarse grain, the DTG curve relative to the nanometric powder is quite different. First, there is a strong difference in the shape of the DTG curves, which indicates that the cation distribution is not the same in coarse and fine particles. This can be explained by the fact that the two types of powders are prepared at different temperatures $\left(500^{\circ} \mathrm{C}\right.$ for nanometric powders, $850^{\circ} \mathrm{C}$ for coarse powders). Second, the oxidation begins sooner in fine powders, which is consistent with the fact that oxidation involves some diffusion mechanisms [3]: for instance, whereas the temperature of oxidation of the $\mathrm{Fe}^{2+}$ cations on $\mathrm{B}$ sites, (which is the oxidation more precisely studied in this paper) is around $250^{\circ} \mathrm{C}$ in coarse powders, it is below $200^{\circ} \mathrm{C}$ concerning the nanometric one. Concerning the comparison between the DTG curves of nanometric powders containing or not $\mathrm{Co}$ ions, it can be emphasized that, when all the oxidizable cations in the spinel 
structure are oxidized, the deviation from stoichiometry is lower in the samples which contain $\mathrm{Co}(\delta=1.17$ in $\mathrm{Fe}_{1.84} \mathrm{~V}_{0.92} \mathrm{CO}_{0.23} \mathrm{O}_{4}, \delta=1.34$ in $\left.\mathrm{Fe}_{2} \mathrm{VO}_{4}\right)$. This is consistent with the fact that in $\mathrm{Fe}_{1.84} \mathrm{~V}_{0.92} \mathrm{CoO}_{0.23} \mathrm{O}_{4}$, some $\mathrm{Fe}^{2+}$ and/or $\mathrm{V}^{2+}$ cations are replaced by some $\mathrm{Cn}^{2+}$ cations which can not oxidize. This point can be also justified by noticing that the rate of oxidation decreases mainly at low temperatures $\left[100-300^{\circ} \mathrm{C}\right]$, which is the range in temperature where there are the bivalent cations which are oxidizing.

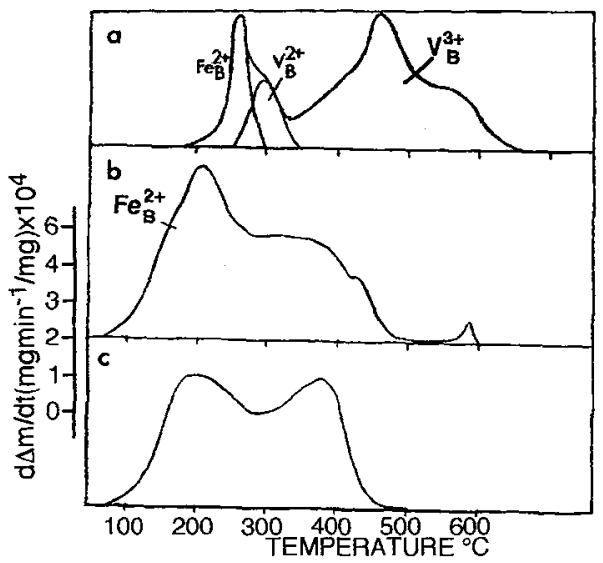

Figure 1: DrG curves of (a) coarse powder of $\mathrm{Fe}_{2} \mathrm{VO}_{4}$, (b) nanometric powder of $\mathrm{Fe}_{2} \mathrm{VO}_{4}$, (c) nanometric powder of $F_{1.84} V_{0.92} \operatorname{Cog}_{23} \mathrm{O}_{4}$

\section{EVOLUTION OF THE COERCIVITY WITH THE Fe ${ }^{2+}$ CATIONS OXIDATION}

When the vanadium ferrites contain some Co cations, there is a strong correlation between the oxidation of the Fe $\mathrm{e}^{2+}$ on the $\mathrm{B}$ sites and the coercivity, as one can see by comparing Figure 1 and Figure 2 . In Figure 2 , the coercivity is measured at room temperature after the same linear heating experiments and quenching at different temperatures. This increase in coercivity is attributed to the creation of a directional order [4] linked to the reorganization of Co cations enhanced by the high content of vacancies created during the $\mathrm{Fe}^{2+}$ oxidation.

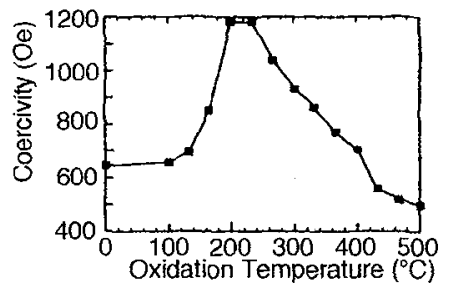

Figure 2: Evolution of the coercive field versus the oxidation temperature in $\mathrm{Fe}_{1.84} \mathrm{~V}_{0.92} \mathrm{Co}_{0.23} \mathrm{O}_{4}$

\section{CONCLUSION}

The reactivity towards oxygen has been investigated in submicron vanadium ferrite spinels using thermogravimetry analysis, FT-IR speciroscopy and XPS. These spinels were prepared by "chimie douce", and the conditions to elaborate the spinel phase were obtained by using $\mathrm{N}_{2} / \mathrm{H}_{2} / \mathrm{H}_{2} \mathrm{O}$ mixtures at $500^{\circ} \mathrm{C}$. When the vanadium ferrites contain some Co cations, correlations have been revealed between the oxidation of the $\mathrm{Fe}^{2+}$ cations on $\mathrm{B}$ sites and the coercivity.

\section{References}

[1] Dieckmann R., Ber. Bunsenges. Phys. Chem. 86 (1982) 112-118.

[2] Nohair M., Pcrriat P., Domenichini B., Gillot B., Thermochim. Acta 244 (1994) 223-234.

[3] Gillot B., J. Solid State Chem. 113 (1994) 163-167.

[4] Tailhades P., Mollard P., Rousset A., Gougeon B., IEEE Trans. Magn. 26 (1990) 1822-1824. 